\title{
Politeness in Selected Independence Anniversary Speeches of Nigerian Heads of Government
}

\author{
Ojo George Adekunle, Omotunde Samuel Adebayo \\ Department of English and Literary Studies, Ekiti State University, Ado-Ekiti, Nigeria \\ Email: georgeade4life@yahoo.com, samueladebayo980@yahoo.com
}

How to cite this paper: Adekunle, O. G., \& Adebayo, O. S. (2017). Politeness in Selected Independence Anniversary Speeches of Nigerian Heads of Government. Open Journal of Modern Linguistics, 7, 290-310. https://doi.org/10.4236/ojml.2017.76021

Received: July 31, 2017

Accepted: December 26, 2017

Published: December 29, 2017

Copyright $(9) 2017$ by authors and Scientific Research Publishing Inc. This work is licensed under the Creative Commons Attribution International License (CC BY 4.0).

http://creativecommons.org/licenses/by/4.0/

\section{(c) (i) Open Access}

\begin{abstract}
The paper analyzes and presents how the phenomenon of linguistic politeness is exhibited in eight selected Independence Day Anniversary Speeches delivered by Nigerian Heads of Government between 1960 and 2011. The speeches were got from both the internet (http://www.dawodu.com.htm) and the national dailies like "The Punch" and "The Guardian" recovered from Archives, University Libraries and Tribune House in Ibadan. Using insights from Leech's Politeness Maxims and Brown and Levinson's theory of "face", it is discovered that either consciously or unconsciously, the speech encoders make use of tact maxim to achieve oneness, intimacy and solidarity with $\mathrm{Ni}$ gerians but most importantly as a face saving act, Pollyanna maxim to conceal the true extent of an unpalatable event and also to make the decoders feel happy and optimistic, modesty maxim to signify that Nigerian Heads of Government are not arrogant and pompous and equally does not claim that they can achieve anything without the support of Nigerians; and lastly approbation maxim to praise, eulogize and acknowledge some selected people in some cases and all Nigerians in others.
\end{abstract}

\section{Keywords}

Linguistic Politeness, Independence Day Anniversary Speeches, Politeness Maxims, Face

\section{Introduction}

Language is an important phenomenon in the affairs of human beings. It is, perhaps, the only singular means of communication that can be overtly used in performing different things or accomplishing different purposes in human so- 
ciety including achieving politeness for the sake of establishing harmony and maximizing friction.

Ambuyo, Indede and Karanja (2011: p. 209) write that "language can be used to encourage, discourage, enhance good communication or even cause conflict between interlocutors, hence, there is need to use polite language for fruitful communication". One of the ways through which language can be used to "enhance good communication" is through the linguistic phenomenon of politeness. The assertion above corroborates the view of Leech (1983: p. 82) that politeness principle in language exists "to maintain the social equilibrium and the friendly relations which enable us to assume that our interlocutors are being cooperative in the first place". Leech (1983: p. 82) further stresses the importance of politeness in language by writing that "unless you are polite to your neighbor, the channel of communication between you will break down and you will no longer be able to borrow his mower". By extension, it equally follows that for any meaningful friendship to take place, for a leader (religious, political, etc.) and his followers to work together successfully and for members of a family to live together peacefully and harmoniously, those involved must exhibit politeness in their linguistic interaction. This explains the reason why Li (2008: p. 32) writes that "the relationship of politeness to cooperation and vice-versa is entwined with one another".

Every society, organization, association, club, tribe, etc. recognizes the importance of using polite language. Hence, politeness is a universal linguistic behaviour. Probably, this is why Adegbija (1989: p. 57) avers that politeness is "a pervasive phenomenon". In the view of Babatunde and Adedimeji (n.d.: p. 3) politeness" is the awareness of another person's "face" or the means employed to acknowledge the public self-image of a person. It is a system of inter-personal relations designed to facilitate interaction by minimizing the potential for conflict and confrontation inherent in all human interactions and transactions".

The concept of politeness is an important one in pragmatics. In the words of Green (1996: p. 151), politeness is "whatever means are employed to display consideration for one's addressee's feelings (or face) regardless of the social distance between the speaker and the addressee". Kienpointer (1999: p. 2) in Odebunmi (2005: p. 3) writes that:

As far as politeness is concerned ... it can be understood as a set of (verbal) routines and strategies which are used to enhance cooperative interaction by establishing and or maintaining in a state of equilibrium the personal relationships between the individuals of a social group.

Grundy (2000: p. 164) writes that "politeness is the term we use to describe the relationship between how something is said to an addressee and that addressee's judgement as to how it should be said". Furthermore, he posits that politeness is used for indicating "the power-distance relationship of the interactants and the extent to which a speaker imposes on or requires something of their addressee".

Denham and Lobeck (2013: p. 346) reveal that: 
Politeness takes many linguistic forms and is somewhat difficult to define. Politeness expresses concern for others but also carries the intention of having this concern reciprocated: we're polite because we want to make others feel at ease, and this in turn makes us more comfortable too. Politeness also crosses social boundaries. Adults and small children can be polite to each other, and the President of the United States would be expected to be polite to a citizen he/she meets on the street even though their social status is dramatically different.

Two important facts about politeness are glaring from the above:

1) Linguistic forms or expressions for expressing politeness cannot be categorically and definitively listed.

2) For interactants in a social situation, the use of polite language should be on a reciprocal basis. In other words, a speaker who is + Higher status must still show considerations for his/her - Higher status audience either in speech or in writing.

It is specifically on the basis of the second point above that this paper would investigate the different forms of politeness in selected Independence Anniversary Speeches of Nigerian Heads of Government. This is based on the belief that there is still a dearth of research work in this area despite the fact that scholars have investigated politeness in political discourse in many areas and climes.

Boicu (2007: p. 1) investigates how modal verbs in Ashley Mote's political speeches "contribute to the mitigation or the aggravation of the illocutionary forces released (sic) by the speech acts they belong to". Li's (2008: p. 32) paper has two main aims - to explore how politicians, especially in political interviews, employ linguistic strategies to resolve the problem "of being un-cooperative and being polite", and "how they save and enhance the face of the party or country they represent while avoiding bringing face-threatening acts". Odebunmi (2009) examines politeness in Tell and The News Magazines using the theoretical framework of relational work and insight from face work and contextualization theories. Ambuyo, Indede and Karanja (2011) examine politeness in Kenyan parliament during Question Time. Apart from the angle of politics, there have also been investigations into the application of the theory of politeness into other areas of which that of Babatunde and Adedimeji (n.d.) and Odebunmi (2005) are significant. However, to the best of our knowledge, no work currently exists on politeness in Independence Anniversary Speeches of Nigerian Heads of Government. It is this gap that the work wishes to fill. In essence, the paper wishes to examine how Nigerian leaders at the highest level employ language to indicate that they show politeness to Nigerians in their Independence Anniversary Speeches. However, the deployment of the linguistic phenomenon of politeness in some of these speeches may be unintentional and unconscious by the speech encoders. For the purpose of clarity and logical presentation of ideas, the remaining part of this work is structured as follows. The second section dwells on theoretical overview of politeness and is followed by the nature and source of the 
data in section three. The fourth section covers data analysis where relevant excerpts from the speeches are used in illustrating the occurrence of the types of politeness strategies identifiable in the speeches. The fifth section is concerned with the discussion of findings. While section six highlights the significance of the research, section seven concludes the paper.

\section{A Theoretical Overview of Politeness}

Mills (2003: p. 6) writes that "politeness is a battery of social skills whose goals is to ensure everyone feels affirmed in social interactions". In essence, it means that politeness in verbal behaviour promotes and enhances friendliness, mutual relationship and interpersonal interaction (Omotunde, 2014). Odebunmi (2005: p. 2) gives a brief insight into the origin of politeness by writing that "the emergence and popularity of the concept of politeness can be traced to the criticism leveled against its precursor, the co-operative principle". Babatunde and Adedimeji (n.d.: p. 4), in shedding light on the popularity and function of politeness write that:

Politeness, as a pragmatic concept, has gained some scholarly attention especially within the last thirty years. It is often interpreted as a strategy (or series of strategies) explored or employed by a speaker to achieve such goals as promoting or maintaining harmonious relations.

Thomas (1995: p. 149) asserts that:

In the past twenty five years within pragmatics, there has been a great deal of interest in "politeness" to such an extent that politeness theory could almost be seen as a sub-discipline of pragmatics. Much has been written... and different theories and paradigms have emerged.

Commenting on the level of research done in politeness, Odebunmi (2009: p. 1) writes that "about nine theories of politeness have been recognized in the literature". Few of these are: Lakoff's (1990) Model, Leech's (1983) Model of Politeness, Brown and Levinson's (1987) Model of Politeness, Fraser (1990) Model of Politeness, Spencer-Oatey's (2000) Model of Politeness etc. However, for the purpose of this paper, we shall adopt Leech's politeness maxims as our main theory. Also, the politeness theory of "face" as conceived by Brown and Levinson (1987) will equally be referred to where applicable. These two theories of politeness will capture the essence of the current research since the data to be analyzed are speeches already committed to the written form rather than interviews or other exchanges where the social context of the interaction and other relevant factors would have to be taken into account. This fact is stressed by Odebunmi (2015: p. 213) when he writes that each of the politeness models:

is applicable to different, sometimes common situations of language use, depending on the interactive features that emerge in human encounters. In other words, they can be selected and applied according to the nature of the data or interactions being dealt with. 
In the words of Leech (1983: p. 131), "politeness concerns a relationship between two participants whom we may call self and other. In conversation, self will normally be identified with $S$ and other will typically be identified with $H$. Leech (1983: p. 132) identifies seven politeness maxims and their sub-maxims:

1) Tact maxim

a) Minimize cost to other

b) Maximize benefit to other

2) Generosity maxim

a) Minimize benefit to self

b) Maximize cost to self

3) Approbation maxim

a) Minimize dispraise of other

b) Maximize praise of other

4) Modesty maxim

a) Minimize praise of self

b) Maximize dispraise of self

5) Agreement maxim

a) Minimize disagreement between self and other

b) Maximize agreement between self and other

6) Sympathy maxim

a) Minimize antipathy between self and other

b) Maximize sympathy between self and other

7) Pollyanna principle.

It is expedient to give further explanations on the maxims above before applying the relevant ones to our data. Going through the literature, it is discovered that the interpretation and explanation of some of the above politeness maxims may have been revised, enlarged, adapted or simplified by some scholars in order to widen their application and usefulness. This is necessary in that in their original explanation, the politeness maxims are best applicable to conversational situations. To this end, the "Tact Maxim" has been simply explained by Ogwuche (2003: p. 123) as "the ability to be tactful or wise in one's utterance, that is, ability to avoid offensive utterance". Odebunmi (2009: p. 4) writing on the manifestation of tact maxim in hospital interactions declares that "a lot of doctor's utterances showed that doctor was considerate to patient and allowed him/her to gain maximum advantage in hospital interaction". He gives examples of the following as tactful use of language by doctors:

1) Kindly tell me your problem (Doctor to patient)

2) We are doing our best for him (Doctor to patient's relative)

3) Do you really feel better? (Doctor to patient)

4) There are two options to this result: it could be positive; it could be negative (Doctor to patient).

The significant point from the above is that Odebunmi adapted "tact maxim" to simply involve considerate use of language in order not to offend somebody 
or hurt one's feelings. In other words, Odebunmi's application of "tact maxim" is very much the same with the denotative meaning of "tact" which according to Chambers $21^{\text {st }}$ Century Dictionary means "an awareness of the best or most considerate way to deal with others so as to avoid offence, upset, antagonism or resentment". This view of tact maxim is what we are going to adopt in this study. The maxim of generosity centres on the belief that others should be put first instead of the self as it concerns directive and commissive acts. Leech (1983: p. 134) summarizes the motives behind maxim of generosity thus: "the idea is that it is more polite, in an offer, to make it appear that the offerer makes no sacrifice, so that in turn it can become easier for $h$ to accept the offer". For "Approbation maxim", Leech (1983: p. 135) writes that this maxim could be further explained or simplified to mean "avoid saying unpleasant things about others and more particularly about hearer". Ogwuche (2003: p. 123) avers that the maxim means "approving of people's behaviour or acceptance of people's failure or weakness". Thus, paying compliments to somebody and eulogizing somebody or his deeds/actions come under approbation maxim. The two sub-maxims of "modesty maxim" which say that "minimize praise of self" and "maximize dispraise of self" agree with Ogwuche's explanation that the maxim "involves humility and sometimes a sense of condescension, i.e., not being vainglorious or boastful". Agreement maxim means that people should express agreement more directly in conversation and that disagreement should be expressed by regret or partial agreement. Leech (1983: p. 138) captures the above by writing that "partial disagreement is often preferable to complete disagreement. Odebunmi (2005: p. 5) writes that "agreement maxim does not mean that disagreement should not be expressed, but rather that they should be expressed in an indirect manner". Sympathy maxim means that people must congratulate others on their achievement, and condole with them when calamity happens to them or befalls them. For Pollyanna principle, according to Odebunmi (2005: p. 5) quoting Leech (1983: p. 147), this principle "states that people will prefer 'to look on the bright side rather than on the gloomy side of life, thus resembling the heroine of Eleanor' H. Porte's 1983 novel, Pollyanna". In a communicative encounter, to say that Pollyanna principle is in operation simply means that interactants/speakers will prefer pleasant topics to unpleasant ones (Leech, 1983: p. 147). In some cases, euphemism may be used in realizing Pollyanna principle. This involves expressing unpleasant or bad events in an inoffensive or pleasant way. According to Leech, another aspect of Pollyanna principle is the tendency to understate the degree to which things are bad. This is summarized by Odebunmi that "The Pollyanna principle can be achieved through euphemisms or relexicalizations and through the use of minimizers such as a bit, a little, a little bit etc., to reduce the degree of badness of something". In summary, the interpretation of the maxims above will greatly increase their application to our data.

Although Thomas (1995: p. 167) has criticized the theory on the basis that "there appears to be no motivated way of restricting the number of maxims", the 
fact remains that its basic substance has not been found to be irrelevant, deficient and inapplicable. Also, the claim by Thomas that the Pollyanna principle has "very limited applicability" may not also be true taking note of the fact that the scholar only paid attention to situations of actual interactions or conversations. In other words, the scholar may not have studied speeches, especially political speeches, where the encoder makes use of Pollyanna principle for rhetorical effect. In this study, we hope to shed light on how politeness is exhibited in the selected speeches with reference to Tact Maxim, Approbation Maxim, Modesty Maxim and Pollyanna principle which have been identified as the ones present in our data.

As mentioned earlier on, the second theory to be adopted in this work is Brown and Levinson's theory of politeness which centres on the concept of "Face". The importance of this theory is revealed by Gyllenhaal (2016: p. 1) when he writes that:

Brown and Levinson (1987) are the authors of the most influential model of politeness strategies. Their theory of politeness is centred on the concept of "face", which, according to their own acknowledgement, is informed by Goffman's (1967) classic account of politeness and the English folk notion of face.

In the words of Yule (1996: p. 60), "Face" refers to the "public self image of a person". Brown and Levinson (2011: p. 286) write that:

Our notion of "face" is derived from that of Goffman (1967) and from the English folk term which ties face up with notions of being embarrassed or humiliated or losing face. Thus, face is something that is emotionally invested, and that can be lost, maintained, or enhanced and must be constantly attended to in interaction.

Thomas (1995: p. 169) reveals that:

Within politeness theory, "face" is best understood as every individual's feeling of self-worth or self image; this image can be damaged, maintained or enhanced through interaction with others. Face has two aspects- "positive" and "negative". An individual's positive face is reflected in his or her desire to be liked, approved of, respected and appreciated by others. An individual's negative face is reflected in the desire not to be impeded or put upon, to have the freedom to act as one chooses.

Closely related to the discussion of positive face and negative face are those of "face saving and face threatening acts". Babatunde and Adedimeji (n.d.: p. 7) declare that "A face saving act is an utterance or action which avoids a potential threat to a person's self image while a face threatening act represents an utterance or an action that constitutes a threat to another individual's expectation regarding self image". Osisanwo (2003: p. 102) distinguishes the two by writing that: 
In an interactive situation, one of the participants can say something that threatens the other person's expectations regarding his public self-image. Such a threat is regarded as a FACE THREATNING ACT. It is possible for the "attacker" to realize that what he has said amounts to an attack on the public self-image of his interlocutors, and may wish to retract his action or statement. Whatever he then says to lessen the possible threat amounts to FACE SAVING ACT (emphasis not ours).

As it is not totally possible in human interaction or communication to avoid face threatening acts to one's hearer, scholars have listed a number of strategies to choose from. Using insight from Thomas (1995: pp. 170-175), the possible strategies are listed below:

1) Perform the FTA without any redress (bald-on record)

2) Perform the FTA with redress (positive politeness)

3) Perform the FTA with redress (negative politeness)

4) Perform the FTA using off-record politeness

5) Do not perform FTA.

\section{The Data}

The data for this research were got from selected Independence Anniversary Speeches of Nigerian Heads of Government between 1960 and 2011. The speeches were got from both the internet (http://www.dawodu.com.htm) and the national dailies like "The Punch", "The Guardian" etc. recovered from Archives, University Libraries and Tribune House in Ibadan. Eight speeches were selected for analysis based on purposive sampling method. The details of the speeches are presented below:

\begin{tabular}{cccl}
\hline Text & Date & Encoder & Administrative background \\
\hline I & Oct. 1, 1960 & Prime Minister Tafawa Balewa & Civilian \\
II & Oct. 1, 1967 & General Yakubu Gowon & Military \\
III & Oct. 1, 1979 & Alhaji Shehu Shagari & Civilian \\
IV & Oct. 1, 1985 & General Ibrahim Babangida & Military \\
V & Oct. 1, 1996 & General Sanni Abacha & Military \\
VI & Oct. 1, 1998 & General Abdulsalam Abubakar & Military \\
VII & Oct. 1, 1999 & Chief Olusegun Obasanjo & Civilian \\
VIII & Oct. 1, 2011 & Dr. Goodluck Ebele Jonathan & Civilian \\
\hline
\end{tabular}

Source: Authors (2017).

It is important to note that the authors have decided to limit the data to 2011 in order to give equal representation of the two categories of Heads of State whose speeches are used in the work. Apart from this, we equally believe that our findings may not be too different from the current one if the Independence Anniversary Speeches of the current Nigerian Head of State-President Muham- 
madu Buhari (2015-Till Date) who is the immediate successor of Dr. Goodluck Ebele Jonathan were to be included in the data.

\section{Data Analysis}

This section deals with detailed analysis of relevant excerpts from our data with the date and the encoder also written.

\subsection{Tact Maxim/Positive Politeness Strategy in the Speeches}

The first instance of the occurrence of this politeness maxim in the speeches is the use of "Fellow Nigerians" or its variants such as "Fellow Citizens and "Fellow Compatriots". The phrase "Fellow Nigerians" or its equivalent functions as a vocative in the speeches. According to Quirk and Greenbaum (1973: p. 182), "A vocative is a nominal element added to a sentence or clause optionally, denoting the one or more people to whom it is addressed and signalling the fact that it is addressed to them". Vocatives perform significant functions in discourse. In the words of Quirk and Greenbaum (1973: p. 183):

One obvious function of a vocative in English is to seek the attention of the person addressed and especially to single him out from others who may be within hearing. A second function, less obvious but certainly no less important, is to express the attitude of the speaker towards the addressee. Vocatives are generally used as a positive mark of attitude, to signal either respectful distance or familiarity varying from mild friendliness to intimacy.

The significance of the vocatives used by the Nigerian Heads of Government as a politeness strategy can further be appreciated by taking note of the comments of DuFon (2010: p. 309) that "clearly, how we are addressed is important to us. Based on how we are addressed, we draw conclusions regarding how that person perceives our relationship to him/her, whether we feel respected or disrespected, accepted, alienated, loved or despised". In essence, the vocatives are used to achieve in-group identity marker. In other words, they are used to indicate rapport, intimacy, oneness, equality, closeness, approval and respect for the listeners. In conclusion, the vocatives are oriented towards the positive face of the listeners (Nigerians).

The Table 1 above clearly indicates that all the encoders use one form of vocatives or the other for equality, friendliness and intimacy. Using insight from Brown and Levinson (1987: p. 103) and Grundy (2000: p. 101), "Fellow Nigerians" or its equivalents is a form of "in-group identity marker" under positive politeness strategy. "Fellow Nigerians" or its equivalents could not be used by Alhaji Tafawa Balewa because the speech he presented on that day was not meant for Nigerians alone in that different people from all parts of the world were in attendance to witness the formal achievement of independence by the country from British.

Apart from the above which is general to all the speeches, other instances of the deployment of Tact Maxim are: 
Table 1. Table of variants and occurrences of the tact maxim or positive politeness strategy in each of the speeches.

\begin{tabular}{cccc}
\hline Date & Encoder & Phrase used & Frequency \\
\hline Oct. 1, 1960 & Alhaji Tafawa Balewa & - & - \\
Oct. 1, 1967 & General Yakubu Gowon & Fellow Nigerians & 3 \\
Oct. 1, 1979 & Alhaji Shehu Shagari & Fellow Nigerians, Fellow Citizens & 3 \\
Oct. 1, 1985 & Gen. Ibrahim Babangida & Fellow Nigerians & 1 \\
Oct. 1, 1996 & Gen. Sanni Abacha & Fellow Nigerians & 12 \\
Oct. 1, 1998 & Gen. Abdulsalam Abubakar & Fellow Countrymen and Women, Fellow & 5 \\
Oct. 1, 1999 & Chigerians, Fellow Citizens & 3 \\
Oct. 1, 2011 & Dr. Goodluck Jonathan & Fellow Nigerians & 3 \\
\hline
\end{tabular}

\section{October 1, 1960-Alhaji Tafawa Balewa}

The main political context surrounding the delivery of the speech was the achievement of the nation's independence from Britain.

a. Recent events have changed the scene beyond recognition so that we find ourselves today being tested to the utmost. We are called upon immediately to show that our claims to responsible government are well founded and having been accepted as an independent state, we must at once play an active part in maintaining the peace of the world and in preserving civilization ... And we come to this task better equipped than many.

The underlined in the above is an exhibition of tact politeness maxim in that Alhaji Tafawa Balewa did not mention the countries or leaders or people of other countries that Nigeria and her leaders are better than so that he would not earn their resentment very early in his administration. In other words, if he had mentioned countries, leaders or people that Nigeria is better than, it would have resulted into Face Threatening Act (henceforth FTA) for them.

\section{October 1, 1967-General Yakubu Gowon}

The main political issue in the country when this speech was delivered centred around the civil war in the country. The following excerpts illustrate the use of tact maxim in the speech:

a) Now is the time for all those people whom Ojukwu has misled to abandon him and his collaborators as it is utterly senseless to prolong the fighting and unnecessary suffering.

b) The Ibos, when they are returned to the fold, must be given their rightful place and as a people who have been misguided and misled by their leaders, the rest of us have a duty to bind their wounds and give them our right hand of fellowship.

In the excerpts above, General Yakubu speaks as if he has no problem with the ordinary Ibos but only with their leaders. He does not call them rebels or disgruntled elements. He only visits his verbal attacks on Lt. Col. Ojukwu (the Biafran leader) and other Biafran warlords. He does not want to offend the general- 
ity of the Ibos. He (Gowon) wishes to woo the Ibos to the side of the Federal Military Government or to weaken their resistance through his speech. It is a politeness tact maxim used for creating divide-and-rule tendency between the ordinary Ibos and their Biafran leaders. In fact, the whole of the second excerpt is to make the ordinary Ibos feel loved, cherished, needed, respected and appreciated.

\section{October 1, 1985-General Ibrahim Babangida}

General Ibrahim Babangida toppled the Buhari led Federal Military Government on August 27, 1985 and became Nigeria's sixth Military Head of State. The following excerpts in the speech illustrate the deployment of tact maxim:

a) Successive Governments have left us with a legacy of economic mismanagement and a chain of political instability.

The speaker above in order to obey tact maxim does not name any particular government in the underlined. It is a tactful way of publicly avoiding embarrassing anybody or a group of persons. It is a face saving act for the purpose of preventing unnecessary resentment and antagonism towards the speaker and his government.

b) ... in view of the magnitude of our economic problems from today, I declare a state of economic emergency for the next 15 months. This emergency period will require strong belt tightening not unlike what we experienced during the civil war. However, we shall ensure that the burden of these emergency measure is distributed as equitably as possible throughout the society.

In the above, there are three instance of the exhibition of tact politeness maxim. In the first underlined, there is the use of litotes or meiosis introduced by "not unlike". This is deliberately done to prevent his listeners from immediately decoding the full meaning and consequences of his utterance. In other words, the utterance means that the emergency measure to be introduced will be like the one introduced during the civil war in extent and in effect, but this is cleverly couched with the use of litotes to prevent anger and resentment since it is not everybody who could easily decode the meaning. Also in the first underlined, there is a tactful omission of "from Nigerians" after "tightening" and before "not unlike". Also, "throughout the society" is a tactful and a neutral use of language.

In other words, the use of "among all Nigerian people" or citizens" would have been more concrete instead of the faceless and abstract "society" which the speaker has cleverly chosen. So, by the omission identified above and the use of "society" instead of "Nigerian people or citizens" the negative effect or hardship which the belt tightening policy or emergency measure will bring is made to be distanced from his listeners (Nigerians) as if it does not concern them as individual. Simply put, it makes the political, financial, psychological and emotional effects of the emergency measure to be less threatening. This tact use of language is necessary so that he (Babangida) would not incur the wrath of Nigerians barely two (2) months into his administration. 


\section{October 1, 1998-General Abdulsalam Abubakar}

General Abdulsalam Abubakar became Nigeria's eighth Military Head of State on June 7, 1998 after the death of General Sanni Abacha who ruled before him.

The most notable instance of the deployment of tact maxim is identified below:

a) In the same vein, this administration will ensure that our fellow citizens are not thrown arbitrarily into police or military detention for every minor infraction of the law ... In addition, we are determined to ensure that every convicted criminal in our jails is treated as human beings. Our prisons should serve as places of reforms not as dehumanizing chambers.

It is important to note that the deployment of tact maxim in the excerpt above can only be appreciated if one knows the political context surrounding its utterance. Before General Abdulsalam took over, General Abacha was noted for throwing people into jail for every minor offence especially people who either directly or indirectly opposed his self-succession bid. General Abdulsalam was fully aware of this development. Those put in jail are tortured, dehumanized and brutalized. Thus, in the above, after "infraction of the law", General Abdulsalam obeyed tact maxim by not saying "like the former administration of General Sanni Abacha did". This is to save Abacha's face even in death and those of his family and sympathizers.

\section{October 1, 1999-Chief Olusegun Obasanjo}

Chief Olusegun Obasanjo was sworn in as the president, Federal Republic of Nigeria on May 29, 1999 after an almost sixteen (16) years of unbroken military rule (Dec. 31, 1983 - May 29, 1999). The most notable instance of the deployment of tact maxim is written below:

a) "... that view is that there must be some divine purpose behind everything that has happened to us as a country. For even in the darkest days of the republic, during the civil war, for instance, or in the more recent days of tyranny, many Nigerians have stubbornly held on to two ...

In the underlined above, there is the deployment of tact politeness maxim in that the speaker does not name any particular administration as the one being referred to. It is a kind of face saving act and a diplomatic use of language in politics. Although the tendency is there for Nigerians and others who are familiar with the political history of the country to associate "more recent days of tyranny" to the Abacha period, the fact remains that the speaker does not mention this himself.

\subsection{Pollyanna Principle in the Speeches}

The principle is well-exhibited in the speeches. Few of the instances of its manifestations are:

October 1, 1967-General Yakubu Gowon

The political context of the speech had been given earlier.

a) Ojukwu made no attempt whatsoever to reciprocate instead, not only were military provocations stepped up on the innocent villages of the Benue/Plateau 
State who had been constantly terrorized by Ojukwu's rebel forces but Ojukwu went as far as declaring total war on the rest of Nigeria and immediately proceeded with the bombing of defenceless civilians in various parts of the country. In the circumstances, I had no choice but to order police action to arrest the situation and to preserve the territorial integrity of Nigeria as well as prevent Ojukwu from subjugating and destroying the five-million non-Ibos in the former Eastern Region of Nigeria, who had all along made clear their desire to remain Nigerians. Fellow Nigerians, you all know what a marvelous job the federal forces have been doing. In the military campaign, so far, we have not lost a single battle.

Reading critically through the excerpt above, it can be inferred that the first underlined is not likely to be an ordinary police action. What comes before it and after it indicate that Gowon might have declared a full scale war too on Biafra. Hence, by saying that he took police action as used above may be a way of ordering a military reprisal attack or counter attack on the East-Central States. In fact, what follows the first underlined justifies our assertion. The second underlined is also a form of Pollyanna politeness principle achieved through euphemism. That is, there may not be anything marvelous which the federal forces could have done in a war situation other than killing and intimidating the Biafrans in the name of bringing unity to Nigeria. In fact, it may be a clever pragmatic way of concealing the horrors being visited by the Federal Military Government on the Biafrans just to make them to capitulate. The above agrees with the position of Thorne (2008: p. 419) that political language is often accused of trying to conceal the truth and euphemism is one common way of making a harsh reality more palatable.

\section{October 1, 1985-General Ibrahim Babangida}

The excerpt below exemplifies the use of Pollyanna politeness principle in the speech:

a) I believe that while we must never forget the scores of the sad lessons of our history, we should not show ourselves to be discouraged or overwhelmed by those unfortunate experiences. Rather, we should draw inspiration from the brighter chapters of our history and in a determined spirit engage the reservoir of our resourcefulness.

In the underlined part of the excerpt above, General Babangida unknowingly or unconsciously makes use of Pollyanna maxim by urging Nigerians to look at the positive aspects of the country rather than reflecting on the issue of civil war, inflation, infrastructural decay etc. He believes that there are many reasonable and positive things about Nigeria that one should reflect on. By not expatiating on what he means by the "the brighter chapters of our history" he assumes that everybody knows what he means or rather he wishes to put his listeners to task to think deeply on the various positive aspects of the country.

\section{October 1, 1996-General Sanni Abacha}

It is imperative to give some contextual information if the significance of the Pollyanna principle in Abacha's speech is to be appreciated. General Sanni Aba- 
cha toppled Shonekan (the nation's Head of Interim Government) and became the country's seventh Military Head of State on November 17, 1993 and died on June 7,1998 . He was a maximum dictator who wanted to perpetuate himself in power. At a point, he wanted to transform to a civilian president. He faced stiff resistance internally and externally from several civil coalition groups in the country. A write up on Abacha in Wikipedia (recovered on 30/7/2011) under the caption "Sanni Abacha" reads:

Abacha is noted for being a monumental kleptocrat and a notorious dictator whose regime executed political opponents, notably Ken Saro-Wiwa. The Abacha family is considered a criminal organization by the Swiss authorities.

Apart from the above, it is also revealed that "during Abacha's regime, a total of $\$ 5$ billion was reported siphoned out of the country's coffers by the Head of State and members of his family". Below are two excerpts from the selected speech which exemplify Pollyanna politeness maxim:

a) In my National Day Broadcast in October last year, I announced the transition programme leading to a democratically elected government on October $1^{\text {st }}$, 1998. The various transition institutions were accordingly established and commenced work within the terms of reference given to them. I am happy to state that considerable measure of success has been recorded since my last National Day Broadcast.

b) Following the remarkable success of the operation of the 1995 budget and the economic reform of the same year, we launched the budget of consolidation in 1996. We considered it necessary to consolidate on our gains of the previous year and move our nation forward. I am happy to state that the mid-year budget report and independent assessment of the performance of the economy in 1996 have shown greater success over that of the previous year. We have now achieved considerable economic stability in various sectors and are in a position to plan ahead for the future.

The two excerpts above exhibit Pollyanna politeness maxim in that they both show the brighter aspects of the administration especially in the area of achievement and performance. It seems as if the speaker is indirectly telling Nigerians that they should take note of his good points in some areas rather than concentrate on his human right abuse or his systematic looting of the nation's treasury as shown by the two quotations above from Wikipedia. Simply put, the reason for making use of the above Pollyanna principle is chiefly political-to make the speech encoder (Abacha) appear as a competent, efficient, dynamic and goal-oriented leader given the political situation of the period.

\section{October 1, 1999—Chief Olusegun Obasanjo}

The only notable instance of the exhibition of politeness maxim is identified below:

a) Indeed when you consider the abundance of our human and material resources, our energy as a people and our seeming exemption from the terrible 
natural disasters such as earthquakes, hurricane, typhoons and droughts that afflict so many other countries, it is tempting to conclude that we are, without doubt, a blessed and fortunate people, and that all we need to conquer therefore is not nature, but only ourselves.

The above is an exhibition of Pollyanna politeness maxim which urges Nigerians to look at the bright side of the country rather than ruminating on the negative happenings around. The excerpt above is for the sole aim of making Nigerians feel proud, hopeful and patriotic. It is a way of assuring Nigerians that no matter the problems (political, social and economic) which the nation may be facing, it is clear that:

1) Nigeria is richly endowed in term of population.

2) Nigeria is abundantly blessed in terms of material and natural resources.

3) Nigerians are energetic and hard working.

4) The country is not prone to natural disasters.

With reference to the above excerpts, the above-listed four points are undebatable, indubitable and unarguable. In other words, the excerpt above informs Nigerians about the brighter aspects of the country which many countries of the word are aware of and which they acknowledged. It makes the hearers feel good.

October 1, 2011-Dr. Goodluck Ebele Jonathan

Dr. Goodluck Ebele Jonathan was sworn-in as the Acting President of the Federal Republic of Nigeria after the demise of the then president-Alhaji Musa Yar'Adua and on May 29, 2011, he was sworn in as the President of the Federal Republic of Nigeria after a general election which he won.

The excerpt below illustrates the manifestation of Pollyanna principle in his speech:

a) Today, as a nation, there is much for us to celebrate. We celebrate our diversity. We celebrate our entrepreneurial skill. We celebrate our resilience and ability to turn adversity into hope. We celebrate our culture.

The excerpt above is meant to serve as a challenge to the pessimists that there is really nothing good about Nigeria to celebrate during the nation's Independence Day. The excerpt points out or highlights some important positive things about the country which should not escape our notice.

\subsection{Modesty Maxim in the Speeches}

Instances of modesty maxim are not common in the speeches under study, although this does not mean that the speakers are "boastful or vainglorious in their presentation of the speeches. The following excerpts are identified as illustrating the maxim:

Oct. 1, 1985

a) I assure you that this administration is determined to face the challenges squarely. The time for action is now. We count on your understanding, cooperation and support.

Oct. 1, 1998

b) I seek the continuous cooperation of all of you which we have enjoyed in 
the last four months of this government to help us accomplish our mission.

\section{Oct. 1, 2011}

c) Together, we shall work for a Nigeria in which democracy and the rule of law are sacrosanct.

All the three excerpts above fall under modesty maxim in that all the speakers said that they need the support and cooperation of Nigerians in order to succeed. In other words, they do not believe that their power, skill, influence and connections alone are enough for them to accomplish their goals without the support of the citizens. It is a way of saying that young or old, educated or uneducated, employed or jobless, men or women, everybody is useful and needed in the development of the country. All the three above fall under positive politeness strategy of "include hearer and speaker in the activity".

Oct. 1, 1999

I have presented to you my humble view of the moral foundations of our administration. What we have done, why and what we propose to do and the responsibilities of every citizen have been made clear.

According to $21^{\text {st }}$ Century Chambers Dictionary, the denotative meaning of "humble" as used above is "lowly", modest or unpretentious". In other words, he meant that he does not see his view as "all-in-all" or "conclusive". An arrogant, boastful or pompous president would have said that "I have presented to you my invaluable and well-thought out view ...”.

\subsection{Approbation Maxim in the Speeches}

\section{Oct. 1, 1967}

It now remains for me to thank on your behalf, our gallant fighting men of the Nigerian Armed Forces. Theirs is a noble role of defending the honour and integrity of this country. They have lived up to expectations and have proved their worth, loyalty and devotion to duty.

The above illustrates approbation maxim in that it praises and acknowledges the bravery and activities of the federal forces in the war being fought that time.

Oct. 1, 1979

I wish to take this opportunity to pay tribute to members of our Armed Forces and to our immediate predecessors in office. They have successfully guided the destiny of our nation through trying conditions. Their discipline, devotion to duty and loyalty to the country have been tested and proved beyond doubt. I trust they will keep it up. You all remember when the Government of General Murtala Mohammed and General Obasanjo came to power, it gave a pledge to return the nation to civil rule on Oct. 1, 1979. They have kept their words as true men of honour, and today the country has been duly handed over to a democratically elected government. History will indelibly record this nation's gratitude to their exemplary leadership, dedication, statesmanship and courage.

It must be remembered that the main tenets of approbation maxim centres around saying something good about the hearer (praising/eulogizing) and ap- 
proving people's behaviour. The excerpt above approves and praises the action of the Armed forces especially General Olusegun Obasanjo who held on to his promise and handed over the reign of government to Alhaji Shehu Shagari in 1979. In this respect, the speaker approves, praises, acknowledges and eulogises the action of those who handed over power to him.

\section{Oct. 1, 1985}

As we celebrate 25 years of the fruits of the endeavour, we acknowledge and salute the courage, foresight, heroism and sacrifice of our nationalist leaders.

Oct. 1, 1996

I seize this opportunity to salute the memory of our founding fathers who endured all hardship to bequeath to us a prosperous and resilient nation.

The above are used to praise and eulogize the nationalist leaders who fought for the country's independence.

Oct. 1, 1999

In this regard, I would like to commend the magnificient work the media in Nigeria has been doing. I am impressed that for the most part, the media have discharged their responsibilities well. They have been indispensable partners as they should be in our moral and ethical crusade and thus deserve to be congratulated for this.

The above is used in order to praise the media for the mature way in which it handles and reports the various activities of the ethnic militia/agitation groups that sprang up when Obasanjo came to power in 1999. In other words, their reportage of issues did not jeopardize national interest and unity.

Oct. 1, 2011

That is the Nigerian spirit: for the Nigerian spirit cannot be broken. We are a resilient nation determined to chart a course through the turbulent waters of nation building... Our citizens at home and abroad are making their mark in all fields of human endeavour... I value all Nigerians.

The speaker above, just like others, makes positive remarks and comments about his listeners. He praises Nigerians and itemizes some of their contributions to national growth and development. Hence, the excerpt falls appropriately under approbation politeness maxim.

\section{Discussion}

Tact maxim is maximally utilized in the data. This takes the form of vocatives like "Fellow Nigerians", "Fellow Citizens", "Fellow Country men and women", My Compatriots". These vocatives are covertly used to pass across the message of solidarity or equality between the speech encoders and other Nigerians. While General Ibrahim Babangida and Dr. Goodluck Ebele Jonathan use it only once in their speeches, General Sani Abacha use "Fellow Nigerians" twelve (12) times. Apart from the conspicuous case of the use of vocatives, deliberate use of comparative adjective "better" fellowed by "than" without mentioning specific name of country in Alhaji Tafawa Balewa's Oct. 1, 1960 speech; the use of "Successive 
Governments" by General Ibrahim Babangida in his 1985 independence address rather than mentioning specific government as being responsible for Nigeria's political and economic woes are other examples of tact politeness maxim in our data.

In the case of General Yakubu Gowon, tact politeness maxim manifests in the way he selects words carefully in order to avoid offending the generality of the Ibos during the civil war. He tactfully uses language in such a way that it is the Igbo leaders that are to be seen as rebels and disgruntled elements rather than all the Ibos. General Abdulsalam Abubakar and Chief Olusegun Obasanjo obey tact maxim through deliberate and careful omission of some phrases and words in their speeches in order to avoid Face Threatening Acts. In other words, the two leaders make use of the above-mentioned tact politeness strategy in order not to make it appear as if they are criticizing the administrations they succeeded.

Another politeness strategy in the data is Pollyanna principle. This takes two forms in our data. The first one is achieved through euphemism in which case the then Head of State, General Yakubu Gowon in the Independence Anniversary speech he delivers was intentionally understated some actions he took and what the federal forces are doing in order to prevent the Biafrans from seceding. For example, when General Gowon says that "Fellow Nigerians, you all know what a marvelous job the Federal forces have been doing. In the military campaign, so far, we have not lost a single battle" (underline ours).

The underlined, for example, obeys Pollyanna maxim by not explaining into detail the full military actions being taken against the Biafran and the horrible consequences on them. The second type of Pollyanna maxim in the data involves dwelling on the brighter side of Nigeria at a particular point in time by the speech encoders. This is meant to make Nigerians feel happy and excited and in the process forget other unpleasant issues plaguing the country at that particular point in time. This politeness maxim has the advantage of making Nigerians to be optimistic. The politeness maxim is used in the address of October 1, 1985, October 1, 1996, October 1, 1999 and October 1, 2011 delivered by General Ibrahim Babangida, General Sanni Abacha, Chief Olusegun Obasanjo and Dr. Goodluck Ebele Jonathan respectively. The next politeness strategy of importance in our data is Approbation maxim. In the words of Gyllenhaal (2016) "approbation guarantees the satisfaction of having one's values approved and of being appreciated and accepted by others". The maxim is adopted in our data to thank and appreciate different categories of people whom the speech encoders feel have played significant roles in the affairs of the country in one way or the other. The last politeness maxim covered by our data is Modesty maxim which is mainly used by the speech encoder to pass across the message that they need the cooperation of all Nigerian in order to move the nation forward.

\section{Significance of the Work}

The current work is significant in various ways. From the social angle, it has re- 
vealed how Nigerian Heads of State exhibit politeness to their listeners. However, it has equally shown that these politeness strategies may be for different reasons of which some may not be known to Nigerians. This means that though some of the politeness maxims obeyed by the Heads of State may genuinely be meant to show intimacy, fellowship, oneness (tact maxim); give assurance, confidence, hope (Pollyanna maxim); show humility and seek support (modesty maxims), and commend persons, group of persons (approbation maxim); the fact remains that the speech encoders may have other reasons or intentions for obeying these politeness maxims. For example, it is revealed in the paper that tact and Pollyanna maxims are used as face saving acts and for preventing Nigerians from immediately decoding the full significance of some portions in the speeches. No previous work on Nigerian political discourse had touched the above area.

Academically, the work is equally significant in that it has revealed the importance of context in appreciating the appropriateness of some politeness maxims obeyed in the work. The paper can also be of pedagogical significance in teaching political discourse in both language class and political science class with reference to how political leaders can improve on their knowledge of exhibiting politeness in their speeches for the purpose of having warm relationship with their citizenry. This will have positive effect on national cohesion, growth and development.

\section{Conclusion}

This work has richly contributed to proper understanding of the concept of politeness and how political leaders exploit it to a maximum advantage. From the analysis, it is evident that Nigerian Heads of Government use politeness strategies in their speeches to make them appear friendly, grateful, appreciative and hopeful. However, the fact remains that the adoption of these politeness strategies by political leaders serves their interest rather than the interest of their hearers/Nigerians. This position agrees with the view of Valeika and Verikaite (2010) quoted in Laurinaityté (2011: p. 13) that politeness is a means of achieving some goals. In essence, the strategies used in our data are chiefly positive politeness strategies which "are usually employed to claim solidarity" (Scollon and Scollon quoted in Izadi (2013)).

\section{References}

Adegbija, E. (1989). A Comparative Study of Politeness Phenomena in Nigerian English, Yoruba and Ogori. Multilingual, 8, 57-80. https://doi.org/10.1515/mult.1989.8.1.57

Ambuyo, B. A., Indede, F. N., \& Karanja, P. N. (2011). Face Threatening Acts and Standing Orders: "Politeness" or "Politics" in the Question Time Discussions of the Kenyan Parliament. International Journal of Humanities and Social Sciences, 1, 209-218.

Babatunde, S. T., \& Adedimeji, M. A. (n.d.). The Theory and Practice of Politeness Phenomena in a Nigerian University. http://www.academia.edu/6224824/Stylistic_Analysis_in_Terms_of_Politeness_in_Gho 
$\underline{\text { sts_by_Henrik_Ib }}$

Boicu, R. (2007). Modal Verbs and Politeness Strategies in Political Discourse. http://mpra.ub.uni-muenchen.de/45913/

Brown, P., \& Levinson (2011). Politeness: Some Universals in Language Usage. In P. Grundy, \& D. Archer (Eds.), The Pragmatics Reader (pp. 283-304). New York, NY: Routledge.

Brown, P., \& Levinson, C. S. (1987). Politeness: Some Universals in Language Usage. Cambridge: Cambridge University Press.

Denham, K., \& Lobeck, A. (2013). Linguistics for Everyone. An Introduction. Wadsworth.

DuFon, A. M. (2010). The Acquisition of Terms of Address. In A. Trosborg (Ed.), Pragmatics across Languages and Cultures (pp. 300-323). Berlin: Walter de Gruyter Monton.

Fraser, B. (1990). Perspectives on Politeness. Journal of Pragmatics, 14, 219-236. https://doi.org/10.1016/0378-2166(90)90081-N

Goffman, E. (1967). Interactional Ritual: Essays on Face-to-Face Behaviour. New York: Anchor Books.

Green, G. M. (1996). Pragmatics and Natural Language Understanding (2nd ed.). Hillsdale, NJ: Lawrence Erlbaum Associates.

Grundy, P. (2000). Doing Pragmatics. London: Hodder Arnold.

Gyllenhaal, J. (2016). Politeness: A Revisit. http://semanticsarchive.net/Archive/GI0NzkwM/Gyllenhaal.pdf

Izadi, A. (2013). Politeness in Spoken Review Genre; Viva Voce Context. Pertanika Journal of Social Science and Humanities, 21, 1411-1429.

Kienpointer, M. (1999). Ideologies of Politeness. Pragmatics, 9, 1.

Lakoff, R. (1990). Talking Power. New York: Basic Books.

Laurinaityté, R. (2011). Hedges in Political Discourse. http://vdd.library.It/fedora/get/LT-eLABa-ooo/:E.02-2011-D_20110627-135924-91163/ DS.oo5./.01.ETD

Leech, G. N. (1983). Principles of Pragmatics. New York, NY: Longman.

Li, S. (2008). A Performative Perspective of Flouting and Politeness in Political Interview. http://www.skase.sk/Volumes/JTL12/pdf_doc/3.pdf

Mills, S. (2003). Gender and Politeness. Cambridge: Cambridge University Press. https://doi.org/10.1017/CBO9780511615238

Odebunmi, A. (2005). Politeness and Face Management in Hospital Conversational Interactions in Southwestern Nigeria. Ibadan: Journal of English Studies, 2, 1-22.

Odebunmi, A. (2009). Politeness in Print Media Political Interviews in Nigeria. https://www.frias.uni-freiburg.de/de/das-institut/archiv-frias/school-of-lili/fellows/ode bunmi_lili

Odebunmi, A. (2015). Pragmatics. In I. Kamalu, \& I. Tamunobelema (Eds.), Issues in the Study of Language and Literature (pp. 196-221). Ibadan: Kraft Books Ltd.

Ogwuche, G. O. (2003). Discourse Analysis. In M. Aliu (Ed.), Linguistics and Literature in Language Arts (pp. 111-140). Kano: Rainbow Royale.

Omotunde, S. A. (2014). A Pragmatic Analysis of Independence Anniversary Speeches of Nigerian Heads of Government. Unpublished PhD Thesis, Ekiti State University.

Osisanwo, W. (2003). Introduction to Discourse Analysis and Pragmatics. Lagos: Femol- 
ous-Fetop Publisher.

Quirk, R., \& Greenbaum, S. (1973). A University Grammar of English. Longman.

Spencer-Oatey, H. (2000). Rapport Management: A Framework for Analysis. In Culturally Speaking: Managing Rapport Through Talk across Cultures (pp. 11-46). London and New York, NY: Continuum.

Thomas, T. (1995). Meaning in Interaction: An Introduction to Pragmatics. London: Longman.

Thorne, S. (2008). Advanced English Language. New York, NY: Macmillan.

Valeika, L., \& Verikaite (2010). An Introductory Course in Linguistic Pragmatics. Vilnius: VPU.

Yule, G. (1996). The Study of Language. Cambridge: CUP. 